\title{
Psychological Capital and Business Success of Chinese, Minangnese, and Javanese Entrepreneurs
}

\author{
Nofri Andri, Puji Tania Ronauli, Benedicta P. Dwi Riyanti \\ Faculty of Psychology, Atma Jaya Catholic University of Indonesia, Jl. Jend. Sudirman 51, Jakarta Selatan 12930 , \\ DKI Jakarta, Indonesia
}

\begin{tabular}{|c|c|}
\hline ARTICLE INFO & A B S T RACT \\
\hline $\begin{array}{l}\text { Keywords: } \\
\text { psychological capital, } \\
\text { business success, } \\
\text { entrepreneur, } \\
\text { chinese, } \\
\text { minangnese, } \\
\text { javanese, } \\
\text { Kata Kunci: } \\
\text { Modal psikologi, } \\
\text { Keberhasilan usaha, } \\
\text { wirausahawan, } \\
\text { etnis tionghoa, } \\
\text { etnis minang, } \\
\text { etnis jawa }\end{array}$ & $\begin{array}{l}\text { Psychological capital (Psycap) is a condition of positive psychology } \\
\text { (hope, efficacy, resilience, and optimism), which facilitates entrepreneurs } \\
\text { to survive in running and reach success in their business. This research } \\
\text { was intended to obtain the overviews of psycap and business success of } \\
\text { Chinese, Minangnese, and Javanese entrepreneurs. There was a total of } \\
207 \text { entrepreneurs involved as respondents. There were two instruments } \\
\text { used in this study: the Psychological Capital Scale and the Balanced } \\
\text { Scorecard. Data analysis method applied to measure psychological capital } \\
\text { was a descriptive statistic. The result showed that Javanese entrepreneurs } \\
\text { had a very high level of psychological capital, while both Chinese and } \\
\text { Minangnese entrepreneurs hold on the same high degree. Meanwhile, the } \\
\text { data analysis regarding the successfulness of business showed that most } \\
\text { of the Javanese entrepreneurs reached a high level of success, Chinese } \\
\text { entrepreneurs were average, and Minangnese entrepreneurs were low. }\end{array}$ \\
\hline
\end{tabular}

SARI PATI

Modal psikologi merupakan kondisi psikologis positif (hope, efficacy, resilience dan optimism) yang memampukan wirausahawan untuk dapat bertahan dalam menjalankan usahanya sehingga mampu mencapai keberhasilan usaha. Penelitian ini melihat bagaimana gambaran modal psikologis dan keberhasilan usaha pada wirausahawan darietnis Tionghoa, etnis Minang, dan etnis Jawa. Sebanyak 207 wirausahawan menjadi responden dalam penelitian ini. Kami meminta para wirausahawan untuk mengisi Psychological Capital Scale dan Balanced Scorecard. Analisis data menggunakan metode statistik deskriptif menunjukkan bahwa sebagian besar psychological capital wirausahawan etnis Jawa berada pada taraf sangat tinggi, sedangkan wirausahawan etnis Tionghoa dan etnis Minang berada pada taraf tinggi. Kemudian, untuk analisis data keberhasilan usaha menunjukkan bahwa sebagian besar wirausahawan etnis Jawa berada pada taraf tinggi, wirausahawan etnis Tionghoa berada pada taraf cukup, dan wirausahawan etnis Minang berada pada taraf rendah. 


\section{INTRODUCTION}

As the capital city of the country, Jakarta holds an important role as the reference of economic growth of Indonesia. However, an optimal populist economic program hasn't been developed. Also, small and medium-sized enterprise (SME) in Jakarta has a very slow growth along the years based on the number of business unit and employment in trading industry.

In 2016, the total of new business units reached 1.235.651 with 4.825.464 workers counted (Badan Pusat Statistik Provinsi DKI Jakarta, 2017). Compared with the 2006 Economic Census, there was an increase by 8,82 percent. But, the provincial government of Jakarta is not yet satisfied and consider this number as a small achievement. SMEs in Indonesia, especially in Jakarta still facing a lot of issues on its way to thrive, making local products stand below their overseas competitor. Some major issues faced by the SME are the limited infrastructure, complicated permit and bureaucracy, high charges, the diversity of social life in the community, the nature of the entrepreneurs, as well as the cultural background of the business persons themselves.

Related to the cultural background, the resemblance or the difference in life value held by the person doing business could be the result of their life experience, personal belief, even history. These factors influence the attitude, behavior, habit, as well as certain sentiment of the entrepreneurs. The multi-ethnical people living in Jakarta are mostly immigrants from other areas that has unique and typical value of life. The ethnical differences will eventually become the characteristic to differentiate one entrepreneur from another (Gray, 1996).

The impact of social culture in driving the development of entrepreneurs through generations is not yet commonly found in business books in Indonesia (Elfindri, Ayunda, \& Saputra, 2010). As economic or financial aspects and biography of successful businessman are the topic mostly discussed. Even so, there is very limited entrepreneurship literature or books that analyze the power of social culture owned by a certain ethnic in creating tough entrepreneurs that can stir the national economy.

Based on an observation held by the researcher in several modern markets (Pasar Glodok, Pasar Senen, Mangga Dua, Pasar Tanah Abang, \& Blok $\mathrm{M})$, the top three ethnics that dominate the industry traffic are the Chinese, the Minangnese, and the Javanese.

The Chinese people in Indonesia are considered as one of the ethnics that hold an important role for the economic improvement of the country, exclusively in the trading sector (Fatmawati, 2005). In constructing their business, the Chinese usually has some traditional values that are held firmly and strongly believed will affect their career, which are hopeng, hongshui, and hokki (Handaru, Pagita, \& Parimita, 2015). These beliefs are put into practice by maintaining a good relationship with business connections and considering the luck aspect in doing their job.

The Minangnese people (often called Padangnese) are very superior in business and education field. As stated in Pelly (1994), the Minangnese usually will migrate to another area to support their life because they have the motivation to prove to the community that they have the ability to succeed in the new place. Besides, the Egalitarian culture amongst the people works as a booster to provide them to become a leader. They have a principle that "it is better to become a leader in a small group than work as a small employee in a big corporation (elok jadi kapalo samuik daripado ikua gajah)" (Elfindri, Ayunda, \& Saputra, 2010). Come to be an entrepreneur is one of the ways to execute that notion. Moreover, by doing business, the Minangnese are able to fulfil their ambition, living life the way they intend it to be, and has a carefree life without any restrain. 
Unlike the Chinese and the Minangnese, the characteristics of the Javanese commonly do not feature the entrepreneurial trait. The researcher has an assumption that interest in doing business amongst the Javanese arises in accordance to the shifting of passion and the opportunity to pursue entrepreneurship. One of the factors that motivates someone to become an entrepreneur is tension modalities (Riyanti, 2009), which happened when someone has a great financial pressure that force them to become an entrepreneur. Initially, the Javanese people were mostly farmer or fisherman, yet the income from these jobs were seen inadequate to meet the day-to-day expense, forcing them to open new business and become entrepreneurs. The Javanese themselves have some core values consist of strong work ethic, avoiding conflict, accept everything sincerely (The so called nrimo or nrima), prioritizing kinship (tuna satak bathi sanak), seeing their job as a way to be granted blessings (laku tirakat), and also giving a maximum effort in doing their job (panggautan gelaring pambudi) (Saksono \& Diwyanto, 2011).

Ethnical values have a contribution in shaping the entrepreneurship attitude. This notion was first mentioned by Weber (see Noseleit, 2010) as he concluded that culture and belief will influence business acts. In addition, Noseleit (2010) found that cultural values will bring impact to personality, that ultimately useful in supporting the work ethics and mentality of the entrepreneur.

The mentality of an entrepreneur will differ so much from an employee who works in a structured organization that applies lots of rules and regulations but offer a small risk to the workers. Entrepreneurs should be able to adapt to the uncertainty of their job, control the risk, and handle the obstacles and different job demands. Riyanti (2009) defines that entrepreneurs must have a business idea and able to do the business, as well as have a sense of independence. Independence are needed to empower entrepreneurs in facing unpredictability, winning business competition, keeping the business alive, along with triggering themselves to become an opportunist. It can be concluded that an entrepreneur is someone who has a strong mentality and independence while dealing with every situation in their business.

Sense of independence could be affected by certain reasons, while one of them is psychological capital (Psycap). Psychological capital (Luthans, Youssef, \& Avolio, 2007) is a psychological condition when an individual develop positively and shows selfefficacy, optimism, hope to achieve success, and resilience in facing obstacles to reach success. Each dimension of psycap has a close connection with the behavior and attitude of entrepreneurs and can be used to assess the way entrepreneurs picturing themselves in reaching success.

If those four aspects of psycap can be maintained, entrepreneurs will have a positive self-asset towards the business and therefore reaching success as their main goal. One research done by Werdiningsih (2016) showed a significant connection between psycap and business success, which means there is a link between psychological capital and the success of an entrepreneur.

Zimmerer and Scarborough (2008) claimed that one of the many ways in assessing business success is through the financial performance. Financial aspect can indicate if a business is considered a success or a failure based on the ability to get the highest profit. Yet the switch from industrial competition paradigm into information competition, has changed, though indirectly, the way people measure whether a business is going to yield some fortune or not. The old approach that based solely on its financial now seems to be inadequate.

Kaplan together with Norton (2000) stressed on the importance of non-financial aspects such as product innovation, business expansion, customer satisfaction, and the development of human resources that can be a stand-out point of a certain business compared to the others. Other 
factors that contribute to human resources are ages, entrepreneurship experience, education, independence, personality or psychological trait, including individual cultural background.

This research is intended to gain the overview of psychological capital and business success of Chinese, Javanese, and Minangnese entrepreneurs in modern market in Jakarta. That overview is expected to assist the development of program that emphasize on the advancement of SME merchant. Also, those results will add a contribution in the database of cross-cultural entrepreneurship, psychological capital, and business success.

\section{Entrepreneur}

Drucker (see Kasmir, 2013) stated that entrepreneurship is an ability to create something new and different. It is also defined as someone who is aware of and able to maximize the opportunity that came along. There are several fashions to increase opportunity, which includes creation, innovation, and the courage to take the risk that comes with it (Kasmir, 2013). Pekerti (see Riyanti, 2009) elaborated that entrepreneurship is a response to business opportunity in the form of a set of acts and resulted in a work of organization that is institutionalized, productive, and innovative.

Creative idea appears when an old product is compared with the new or different ones. Entrepreneurs usually act based on opportunity that they believe will lead them to achievement. They are the people who have the ability to analyze and evaluate business chance, gather and manipulate resources to attain its highest function and take the initiative to reach goal.

Entrepreneurship also can be identified as a soul or the spirit of independence in a person. This independence included the capacity to keep on track in every situations and has the competency to modify any upcoming chance to be profitable (Riyanti, 2009). In a conclusion, entrepreneur is someone who holds the competence in viewing business opportunity and willing to take the risk to gain benefit for themselves, others, together with the community.

\section{Psychological Capital}

Luthans, Youssef, and Avolio (2007) defined psychological capital or psycap as a psychological state of a positively developing individual who has (1) self-efficacy to choose and decide the kind of effort needed to succeed in challenging task; (2) an optimism for future success; (3) determination in reaching goal, and ability to lead the way towards the goal; (4) patience and resilience in facing problems that enable them to rise higher than before.

The combination of those four interconnected dimensions are the construct of psycap that can indicate the way individual holds positive organization behavior. The missing of one of the four may lead to absence of psychological capital (Tania \& Dahesihsari, 2017).

An evolving individual may continuously grow their psychological capital, making their mentality tougher and their capacity to raise their stance expand. Ever growing entrepreneurs that maintain their psychological capital will try to keep on boosting their welfare along with their satisfaction towards their job, thus in the end, it will lift their psycap maximally (Hmieleski \& Carr, 2007).

\section{Business Success}

Assessing financial performance is the first step to quantify if a business is successful or not. Nonetheless, this method has its own weakness, which is it cannot measure the intellectual treasure such as human resources, including in a scale as small as SME. Kaplan and Norton (see Riyanti, 2009) suggested balanced scorecard as the tool to measure business success. According to Zimmerer and Scarborough (2008), business success can be indicated through (1) the rise of the sales, (2) the increase of production, (3) the increase of profit, and (4) the rapid and satisfactory growth of the business. 
Balanced scorecard is a method to assess business performance through four perspectives, which are financial, customer, internal business process, and learning and growth process. Through this instrument, business success is seen as a condition when there is continual increase of the sales, and the profit rises, the business has the power to survive, goal can be achieved, the number of customer increase, well-maintained internal business process, and there is a learning process and growth inside the business.

\section{Ethnic}

Ethnical issue has been a central matter in a diverse country such as Indonesia. In Indonesian context, ethnic can be defined as a restriction of culturalsocial identity that differentiate one ethnic group with the others (Lan, 2006). Ethnic groups are made of numerous people who share the same value and believe, or something believed together built upon their country origin, a common ancestor, a place of birth, distinctive social characteristics (Religion, style of dress, or language) that set them apart from other ethnic groups (Ferrante, 2011). The values and beliefs held together in an ethnic group can influence people in daily life as well as when they do their job.

There are three ethnics that dominate the trading industry, which are Chinese, Minangnese, and Javanese. The Chinese has three specific values that are held up high and believed will bring good luck in both social and economic life, they are hopeng, hongshui, and hokki. In the Minangnese community, become the leader of a small group is always considered better than becoming a small person in a big company (elok jadi kapalo samuik daripado ikua gajah). Whilst in the Javanese culture, they feature acting passively against any possibilities that might happen (nrimo or nrima), prioritizing kinship (tuna satak bathi sanak), seeing their job as a way to be granted blessings (laku tirakat), and also giving a maximum effort in doing their job (panggautan gelaring pambudi) (Saksono \& Diwyanto, 2011).

\section{Modern Market}

Rahadi (2010) explained market as a meeting place for both sellers and buyers so the trading of the goods may happen. Meanwhile in accordance with the Ministry of Trade of The Republic of Indonesia Regulatory Number 70 (2013), market is defined as the sale and purchase of goods area with the number of sellers more than one, as well as shopping centers, traditional markets, shops, malls, plaza, trade centers and other designations.

The Ministry of Trade is modernizing traditional market without removing its unique characteristic. This act is done to empower traditional market in the competition field with the modern market that offers a pleasant, safe, yet affordable shopping ambience. This attempt will also work as a rebranding to obtain a tidier and organized management system through its human resource development.

\section{METHODS}

\section{Participant and Procedure}

This research included 207 entrepreneurs from modern markets in Jakarta namely Pasar Senen, Pasar Glodok, Mangga Dua, Pasar Tanah Abang, Pluit, and Blok M. Data were obtained with purposive sampling that looked for Chinese, Minangnese, or Javanese entrepreneurs who have owned a small and medium-sized enterprise (SME) for at least six months.

Self-report method or survey was used in this study in the process of gathering current situation of the participants (Coolican, 2014). This questionnaire consists of four parts including the informed consent, biography section to collect demographic data, the psychological capital questionnaire, and the balanced scorecard. All participants filled out questionnaires without any pressure and with a guarantee of confidentiality of the information.

A total of 143 male and 64 female entrepreneurs joined this study, with their age ranging from 18 up to 40 years old. There are 64 Chinese, 53 Minangnese, and 90 Javanese entrepreneurs 
involved. Most participants of this study have a type of large and retail trading business, repair and maintenance of cars and motorbikes, the provision of accommodation, and provision of drinking meals. Statistic analysis approach was descriptive method.

\section{Measures}

Psychological Capital. Psychological capital questionnaire (PCQ) developed by Luthan, Avolio, and Avey (2007) was used. In prior, PCQ was adapted in Indonesian and adjusted to match the entrepreneurship framework. PCQ contains 24 items that evaluated the four domains of psycap, hope, self-efficacy, resilience, and optimism. There were six items in Likert scale to measure each domain. The measuring instrument can be said to be valid if the measuring item has a significance value below 0.05 or a correlation value above critical value. Respondents for try out amounted to 70 people who work as entrepreneurs, then the critical value for testing Spearman correlation with a significance of 0.05 was 0.344 . Based on the validity test of 24 PCQ items, it can be seen that all items are valid with moving values from 0.551 to 0.797 . The assessment of internal consistency using Cronbach's alpha showed a sufficient result (hope $=.87$, self-efficacy $=.87$, resilience $=.82$, and optimism $=.82$ ).

Business Success. The Balanced Scorecard (BSC) were developed in a study titled "Optimism and Business Success in Betawi Entrepreneurs" (Guritno, 2015). This measuring tool has a total of 11 items spread in financial domain (4 items), customer aspect (2 items), and internal business process (5 items). Respondents for try out amounted to 70 people who work as entrepreneurs, then the critical value for testing Spearman correlation with a significance of 0.05 was 0.344 . Based on the validity test of 11 BSC items, it can be seen that all items are valid with values moving from 0.896 to 0.933 Cronbach's alpha for BSC was satisfactory (financial $=.98$, customer $=.94$, and internal business process $=.98)$.

\section{RESULTS AND DISCUSSION}

Desciptive Statistic

The scores gathered from participants' answer were put into categories ranging from very low up to very high.

Table 1. Descriptive Statistic Psychological Capital

\begin{tabular}{|c|c|c|}
\hline Ethnic & Mean & SD \\
\hline \multicolumn{3}{|l|}{ Self-efficacy } \\
\hline Chinese & 27.6 & 6 \\
\hline Minangnese & 26 & 7 \\
\hline Javanese & 31 & 4 \\
\hline \multicolumn{3}{|l|}{ Hope } \\
\hline Chinese & 28 & 5.5 \\
\hline Minangnese & 26 & 7 \\
\hline Javanese & 31 & 4 \\
\hline \multicolumn{3}{|l|}{ Resilience } \\
\hline Chinese & 27 & 5 \\
\hline Minangnese & 27 & 5.5 \\
\hline Javanese & 31 & 4 \\
\hline \multicolumn{3}{|l|}{ Optimism } \\
\hline Chinese & 27 & 5.7 \\
\hline Minangnese & 26 & 7 \\
\hline Javanese & 31.7 & 4 \\
\hline \multicolumn{3}{|l|}{ Psychological Capital } \\
\hline Chinese & 110 & 21 \\
\hline Minangnese & 106 & 25 \\
\hline Javanese & 125 & 15 \\
\hline
\end{tabular}

The empirical mean in Table 1 showed the highest measure of psychological capital was held by Javanese entrepreneur ( $\mathrm{M}=125.32)$, second by Chinese ( $M=110.45)$, and Minangnese with lowest mean point by 106.49. Consecutively, that number led Javanese businessperson to a very high category, whilst the Chinese and the Minangnese stayed at high level.

Traced deeper in each dimension, the majority of Javanese respondents earned a very high average ( $\mathrm{M}=31.41$ for hope, $\mathrm{M}=30.95$ in self-efficacy, $\mathrm{M}$ $=31.21$ in resilience, $\& \mathrm{M}=31.74$ for optimism). 
Meanwhile, nearly all Chinese had a high average for those four dimensions ( $\mathrm{M}=28.06$ for hope, $\mathrm{M}$ $=27.65$ in self-efficacy, $\mathrm{M}=27.34$ in resilience, $\& \mathrm{M}$ $=27.39$ for optimism). Similar case also happened amongst the Minangnese with the average for hope ( $M=26.54)$, self-efficacy $(M=26.03)$, resilience $(\mathrm{M}=27.49)$, and optimism $(\mathrm{M}=26.41)$ was high.

Table 2. Descriptive Statistic Business Success

\begin{tabular}{ccc}
\hline Ethnic & Mean & SD \\
\hline Financial & & \\
\hline Chinese & 8.6 & 6.8 \\
Minangnese & 7.8 & 6.3 \\
Javanese & 12.3 & 5.8 \\
\hline Customer & & \\
\hline Chinese & 4.6 & 3.2 \\
Minangnese & 4 & 3.2 \\
Javanese & 6.2 & 2.8 \\
\hline Internal Business Process & & \\
\hline Chinese & 11 & 8.5 \\
Minangnese & 9.7 & 8 \\
Javanese & 15.4 & 15.4 \\
\hline Business Success & & \\
\hline Chinese & 24.3 & 24.3 \\
Minangnese & 21.7 & 21.7 \\
Javanese & 34 & 34 \\
\hline
\end{tabular}

Table 2 showed the overview of business success throughout the ethnical group. In descending order, the empirical averages of each ethnic group were 34.02 for Javanese, 24.39 held by Chinese, and lastly 21.73. These calculations spread each ethnical group into high category (Javanese), sufficient (Chinese), and low (Minangnese).

The readings for each dimension were more varied. Javanese entrepreneurs were seen to hold a high category in the internal business process dimension $(\mathrm{M}=15.48)$, middle level in the financial dimension $(\mathrm{M}=12.33)$, and low for the customer dimension $(\mathrm{M}=6.2)$. Chinese group's average amongst its dimensions were also not similar. It was considered sufficient in the internal business process dimension (11.1), low in financial (8.64), and very low in customer dimension (4.64). Entrepreneurs from Minang ethnic group had a low average point in two dimensions ( $\mathrm{M}=9.79$ for internal business process $\& M=7.84$ in financial), yet they scored very low on the customer dimension $(\mathrm{M}=4.09)$.

\section{Discussion}

There are some interesting findings in this report. Seeing a better score of PSQ in the Javanese ethnic group indicated the shift of interest in choosing a job. This also confirmed the assumption of the author. This kind of switch appears when there are urges and a great chance to own a business (Saksono \& Diwyanto, 2011).

Overall, Javanese businessperson has a high rate optimism and hope. Based on their belief and values, the Javanese prioritize the harmony and work ethics when doing business. Some fundamentals namely panggautan gelaring pambudi (put a maximum effort in achieving their goal), and the need to have nrimo (accept the results of his business sincerely).

The concept of panggautan gelaring pambudi and nrimo has a parallel concept with optimism and hope. While optimism is a positive mindset towards what is aimed, and hope is the need and will to keep on finding the way for success. The combination of those two might triggered a persistent manner and eventually bring forth the commitment to run their business (Trevelyan, 2008). These considerations are in line with the attitude of Javanese people that are independent, persistent, as well as hardworking to obtain their expectation (Saksono \& Diwyanto, 2011). The two value are mention above are likewise embedded in the mind of Javanese entrepreneurs while performing in every work.

In Chinese entrepreneurship, inherited values and thoughts are used to protect the fluency and achievements in their business. In this study, the Chinese group attained high scores in the dimension of hope and self-efficacy. In an 
exploration done by Debbie Liao and Philip Sohmen (see Sakur, 2006) Chinese has a sense of confidece, able to find the way in a situation of misfortune, persevere. In operating a business, Chinese were very prominent in their hard work, perseverance, and their bravery in facing failure. Hokki and hongshui were carried in every business aspects, making Chinese entrepreneurs will always search the path to earn good luck and gain a lot of profit in doing business (Handaru, Pagita, \& Parimita, 2015). The hopeng point of view help them to nurture a favourable relation with colleagues and customers. By maintaining that relation, Chinese entrepreneurs admit that it will open the doors to more beneficial partnership (Seng, 2007).

In the frame of Minangnese entrepreneurs, business is not merely a field to find a living, yet it also has a role to prove their existence in the community. In the previous section, businessperson from Minang ethnic has a high mark on resilience. This notion was also approved by Maulidya and Eliana (2013) that the majority of Minangnese entrepreneur who left their hometown has a strong resilience. This finding interpreted how the Minangnese is prepared to endure difficult times and still exist in their community. Otherwise, the chance of successful business is considered low for this ethnic group. This convinced that the Minangnese are maybe starting to abandon one of their cultural value, "elok jadi kapalo samuik daripado ikua gajah". Elfindri, Ayundan, and Saputra (2010) pointed that transition of social life might loosen the potency of Minangnese people in the entrepreneurship field. They specified that young generations of Minang ethnic are more likely to work as an employee rather than be self-employed. Furthermore, they also stressed the hardship of Indonesian economic condition, which took side on the macro business counterpart, along with the education system that tried to produce an excellent employee.

Several defects of this study revolve around its sampling technique that reduce the variety of participants assessed. Chinese respondents were chosen from Pasar Glodok and Mangga Dua, while
Minangnese gathered from Tanah Abang, and the majority of Javanese entrepreneurs open their business in Blok M and Tanah Abang. The specific location where respondents were picked, and the number of each participants might bring an impact to the final result of this study, creating an overly exclusive context that hard to be generalized. However, these findings and considerations is expected to contribute in the design of forthcoming studies related to psychological capital and business success in entrepreneurs with different cultural background. Especially those that centralize on the Chinese, Minangnese, and Javanese entrepreneurs.

\section{MANAGERIAL IMPLICATIONS}

Psychological capital is necessary to be managed in achieving a successful business. A hope for business development, self-efficacy in creating favourable relation with customer, perseverance in attaining goal, and optimism for business expansion were needed to empower entrepreneur to be successful. This research was intended for:

1. Government agencies, including The Department of Cooperatives and SmallMedium Enterprises and higher educational institution to motivation for the current and future entrepreneur. This might be realized by providing the business-related information needed by the society through trainings, seminars, or educational system. For a successful entrepreneurship acts as one of the professions that strengthen the economy of a country.

2. Specialized organization for entrepreneurship development. Providing a complete fundamental for future entrepreneur such as in finding business opportunity, building business connection, business managerial, and product or service selling would be a great psychological capital for the business to success.

\section{CONCLUSION}

As stated above, it can be concluded that Javanese entrepreneurs tend to have a very high level of 
psychological capital as well as a high level of business success. Chinese entrepreneurs have a high level of psychological capital, but their business success falls on the middle level. Whereas psychological capital of Minangnese entrepreneurs also lies on a high level, conversely, they have a low level of success in doing business. Javanese businessperson has the highest rate of both psychological capital and business success.

Objectively, there are a few limitations in this research that future researcher should avoid. The respondents in this research have a very specific location of origins, which hinder this study to be generalized in different situation. Also, the result of this research might be treasured deeper for future studies regarding the connection between psychological capital and business success in Chinese, Minangnese, and Javanese entrepreneurs. Further research also needs to consider the type of business of entrepreneurs. Psychological capital research with business success, should be examined in entrepreneurs from various ethnic backgrounds but with the same type of business or relatively the same so as to reduce the bias of research results due to different types of businesses.

REFERENCES

Badan Pusat Statistik Indonesia. (2017). Keadaan Ketenagakerjaan Indonesia Februari 2017. Jakarta: Badan Pusat Statistik.

Badan Pusat Statistik Provinsi DKI Jakarta. (2017). Hasil Pendaftaran (Listing) Usaha/Perusahaan Sensus Ekonomi 2016. Jakarta: Badan Pusat Statistik.

Bintoro, R. W. (2010). Aspek Hukum Zonasi Pasar Tradisional dan Pasar Modern. Jurnal Dinamika Hukum, page 351.

Coolican, H. (2014). Research Methods and Statistics in Psychology. New York: Psychology Press.

Elfindri, Ayunda, D., \& Saputra, W. (2010). Minang Entrepreneurship: Filosofi dan Rahasia Sukses Etnis Minang Membangun Karakter Kewirausahaan. Jakarta: Boduose Media.

Fatmawati. (2005). Perilaku Kewirausahaan Kelompok Etnik Melayu, Minang, dan Cina Keturunan dalam Pengembangan Usaha. Yogyakarta: Fakultas Psikologi Universitas Gajah Mada.

Ferrante, J. (2011). Seeing Sociology: An Introduction. USA: Wadsworth Cengage Learning.

Gray, D. (1996). Anda Siap Sebagai Wiraswasta. Jakarta: Arcan.

Guritno, G. D. (2015). Gambaran Optimisme dan Keberhasilan Usaha pada Wirausaha Etnis Betawi. Skripsi. Jakarta: Fakultas Psikologi UNIKA Atma Jaya.

Handaru, A. W., Pagita, M. P., \& Parimita, W. (2015). Karakteristik Entrepreneur Melalui Multiple Diskriminan Analisis: Studi Pada Etnis Tionghoa, Jawa dan Minang di Bekasi Utara. Jurnal Riset Manajemen Sains Indonesia, pages 351-375.

Hariyono. (1994). Kultur Cina dan Jawa: Pemahaman Menuju Asimilasi Kultural. Jakarta: Pustaka Sinar Harapan.

Hmieleski, K. M., \& Carr, J. C. (2007). The Relationship Between Entrepreneur Psychological Capital and Well-Being. Frontiers of Entrepreneurship Research, pages 1-12.

Kaplan, R., \& Norton, D. P. (2000). Balanced Scorecard: Menerapkan Strategi Menjadi Aksi. Jakarta: Erlangga.

Kasmir. (2013). Kewirausahaan-Edisi Revisi. Jakarta: PT. Rajagrafindo Persada.

Lan, T. J. (2006). Redefinisi Etnisitas dalam Konteks Kebudayaan Nasional. Jurnal Masyarakat dan Budaya, 8, pages 123-140.

Lembaga Pengembangan Perbankan Indonesia. (2015). Profil Bisnis Usaha Mikro, Kecil dan Menengah (UMKM). Dipetik November 12, 2016, from www.bi.go.id: http://www.bi.go.id/id/umkm/penelitian/nasional/kajian/Documents/Profil\%20 Bisnis\%20UMKM.pdf 
Luthans, F., Youssef, C. M., \& Avolio, B. J. (2007). Psychological Capital: Developing the Human Competitive Edge. New York: Oxford University Press.

Maulidya, M., \& Eliana, R. (2013). Gambaran Resiliensi Perantau Minangkabau yang Berwirausaha di Medan. Psikologia, pages 34-39.

Noseleit, F. (2010). The Entrepreneurial Culture: Guiding Principles of the Self-Employed. Entrepreneurship and Culture, pages 41-54.

Pelly, U. (1994). Urbanisasi dan Adaptasi : Peranan Misi Budaya Minangkabau dan Mandailing. Jakarta: Pustaka LP3ES Indonesia.

Republik Indonesia. (2013). Peraturan Menteri Perdagangan Republik Indonesia No. 70/M-DAG/PER/12/2013 tentang Pedoman Penataan dan Pembinaan Pasar Tradisional, Pusat Perbelanjaan dan Toko Modern. Jakarta: Menteri Pedagangan Republik Indonesia.

Riyanti. (2009). Kewirausahaan Bagi Mahasiswa. Jakarta: Universitas Katolik Indonesia Atma Jaya.

Riyanti, B. P. (2009). Kewirausahaan Bagi Mahasiswa. Jakarta: Universitas Katolik Indonesia Atma Jaya.

Saksono, I. G., \& Diwyanto, D. (2011). Terbelahnya Kepribadian Orang Jawa: Antara nilai-nilai luhur dan praktik kehidupan. Yogyakarta: Keluarga Besar Marhaenis DIY.

Seng, A. W. (2007). Rahasia Bisnis Orang Cina. Jakarta: PT. Mizan Publika.

Sudaryanto, Ragimun, \& Wijayanti, R. R. (2013). Strategi Pemberdayaan UMKM Menghadapi Pasar Bebas Asean. Pusat Kebijakan Ekonomi Makro, Badan Kebijakan Fiskal. Jakarta: Kementerian Keuangan.

Tania, P., \& Dahesihsari, R. (2017). Descriptive Study about Psychological Capital for The Sales Office Head at PT. Astra International, TBK - Honda Sales Operation. MANASA: Jurnal Ilmiah Psikologi, pages 154-162.

Trevelyan, R. (2008). Optimism, Overconfidence and entrepreneurial activity. Management Decision, 986-1001.

Werdiningsih, B. (2016). Hubungan antara Psychological Capital dan Keberhasilan Usaha pada Wirausaha. Skripsi. Jakarta: Fakultas Psikologi UNIKA Atma Jaya.

Yousaf, U. S., Hanfiah, M. H., \& Usman, B. (2015). Psychological Capital: Key to Entrepreneurial performance and Growth intentions. International Research Journal of Social Sciences, 39-45.

Zimmerer, T. W., Scarborough, N. M., \& Wilson, D. (2008). Kewirausahaan dan Manajemen Wirausaha Kecil. Jakarta: Salemba Empat.

Zimmerer, T., \& Scarborough, N. M. (2008). Essential of Entrepreneurship and Small Business Management (5th ed.). Upper Saddle River, New Jersey: Pearson Education. 